\title{
Red discoloration of the sputum by clofazimine simulating haemoptysis - A case report
}

\author{
A GIRDHAR, K VENKATESAN, S L CHAUHAN, \\ G N MALAVIYA \& B K GIRDHAR* \\ Central JALM A Institute for Leprosy, Tajganj, Agra-282001, India
}

Accepted for publication 24 August 1991

Summary A patient of lepromatous leprosy, who received a high dose of clofazimine as part of multidrug therapy, for chronic erythema nodosum leprosum (ENL) had frequent 'haemoptysis'. The haemoptysis was later found to be due to expectoration of clofazimine. This interesting, and perhaps first case of such an occurrence, is reported.

\section{Introduction}

In January 1989 AA, A 17-year-old slightly-built male tailor, was first seen in the clinic with a 2-year history of a hypopigmented macule over the abdomen. The lesion had regressed without any specific treatment. For the previous 5-6 months the patient had had about 5 recurrent attacks of erythema nodosum leprosum (ENL), which lasted between 10 and 30 days. These reactional episodes were controlled by steroid tablets $-2-8$ per day with occasional steroid injections that were prescribed by local GPs. This treatment produced a temporary remission each time. New attacks occurred whenever the therapy was stopped. His brother has lepromatous leprosy, and almost certainly the mother had the disease too.

When he was examined, there was a diffuse shine over his face, back and buttocks, together with symmetrical, painful, tender red papules and nodules over his back and the extensor sides of the proximal parts of the limbs. There was some thickening of his earlobes. He had symmetrical nerve thickening involving ulnar, radial-cutaneous, lateral popliteal and superficial peroneal nerves. The right ulnar nerve was grossly thickened, tender to touch, and firm. He had symmetrical impairment of sensations over distal parts of his limbs. Except for a mild right ulnar nerve weakness, he had no paralytic or secondary deformities. No systemic abnormality was found.

His skin smears were +3 (Ridley) and the response to Dharmendra lepromin antigen was negative at $48 \mathrm{hr}$. He was diagnosed as a subpolar lepromatous leprosy case with chronic ENL and was put on multidrug therapy (MDT) with clofazimine (CLO) $300 \mathrm{mg} /$ day along with thalidomide $(300 \mathrm{mg} /$ day). By day 8 , the reaction had subsided. The

* Correspondence and reprint requests 
dosage of CLO was reduced gradually to $100 \mathrm{mg} /$ day by the end of week 5 , but the patient still suffered from recurrent pain in both ulnar nerves, with more pain on the right side. The right ulnar nerve was surgically decompressed. The patient improved and was discharged.

After approximately 10 months' treatment he complained of a cough with bloodstained sputum, and breathlessness, which had lasted for about 10 days. There was no history of fever, reduced appetite or loss of weight. His chest was clear; the sputum was negative for acid-fast bacilli (AFB), both on microscopy and Lowenstein-Jensen (LJ) medium culture. A chest X-ray showed no abnormality, ruling out pulmonary tuberculosis. His total leucocyte count was $8400 \mathrm{~cm}^{2}$ (polymorphs $38 \%$, lymphocytes $32 \%$ and eosinophils $30 \%$-total eosinophil count of $\left.2520 / \mathrm{cm}^{2}\right)$. No parasites were seen in the blood under the microscope and the red blood cell count was normal. We diagnosed a case of tropical pulmonary eosinophilia, so put the patient on diethyl carbamazime (DEC $300 \mathrm{mg} /$ day), and within 10 days there was a temporary remission of dyspnoea and 'haemoptysis'. The above investigations were repeated (eosinophilia of 14\%) and he was discharged with advice to continue DEC for 10 more days. He returned again 1 month later with the same problem of blood-stained expectorate; his results, except for a raised eosinophil count, were normal. There was no growth of bacteria on a LJ medium culture, which ruled out tuberculosis. Even though red, the sputum did not show any erythrocytes (by smear) or haemoglobin (by benzidine test). No abnormal cells were seen in the sputum, which ruled out malignancy. The sputum was subjected to a CLO test using the technique of Desikan \& Balakrishnan. ${ }^{4}$ The presence of CLO was checked by a high performance thin-layer chromatographic ${ }^{6}$ procedure which showed that the reddishbrown streaks in the sputum (Figure 1) were caused by a large amount of CLO; this was confirmed by repeat sputum examinations. For the last 4 months of treatment CLO has been replaced by prothionamide, and the reddish streaks in the sputum decreased in the following month and have been absent for this 4-month period. However, a repeat sputum examination ( 4 months after stopping CLO) did show some needle-shaped CLO crystals, though the sputum was clear on gross examination. The clofazimine contents of saliva spat out was $0.082 \mu \mathrm{g}$ per gram.

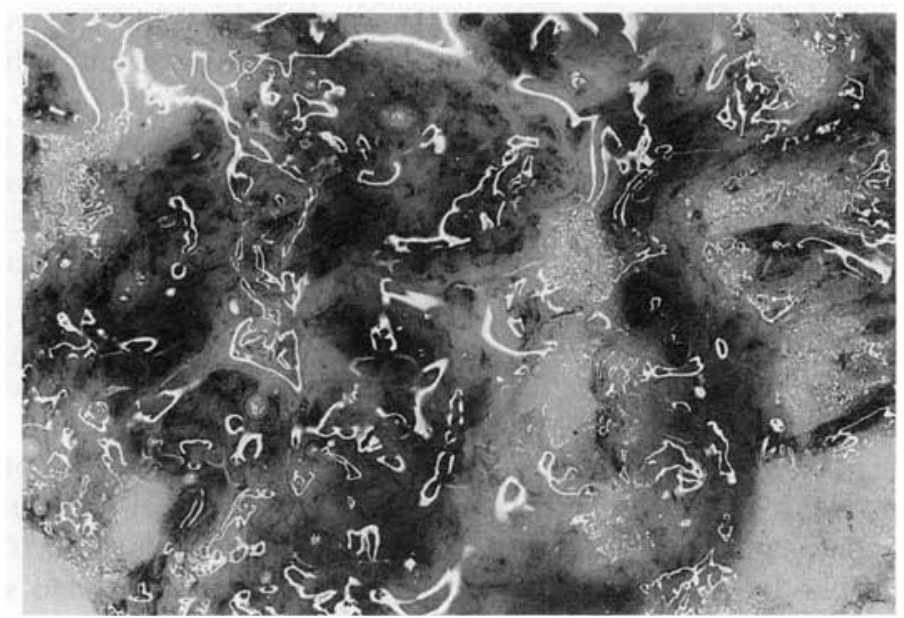

Figure 1. Macroscopic appearance of sputum showing a large amount of clofazimine. 


\section{Discussion}

Apart from being an effective antileprosy drug, clofazimine is also useful in the management of ENL reactions, ' and is helpful in the withdrawal from steroids in steroiddependent cases. However, since the anti-inflammatory effect of the drug is slow, a dose of about $300 \mathrm{mg} /$ day has to be continued for a long time (about 8-12 weeks). In some reports, an even longer use of the drug in high doses was necessary to control recurrent ENL and/or steroid withdrawal. ${ }^{2}$ It has been shown, both in mice ${ }^{3}$ and in man, ${ }^{4}$ that the distribution of the drug is very uneven throughout the body. In the skin itself, it is well known that the CLO levels are higher at sites of infiltration, where macrophages abound, as opposed to the uninfected skin of the same patients. Postmortem studies ${ }^{4,5}$ have shown that the intestines and the reticulo-endothelial tissues have a far greater load of CLO than other tissues. Large amounts of CLO have been found to be deposited in the liver, gut and lung parenchyma. Concentrations in the lung of $17 \mathrm{mg} / \mathrm{g}$ of lung tissue have been reported. ${ }^{4}$

This patient had 'haemoptysis' after he had taken $34 \mathrm{~g}$ of CLO. As he did not show any particular CLO coloration of skin or symptoms suggesting any gut involvement, this suggests that in his case the lungs were possibly the site of the excessive CLO deposition.

Clofazimine is known to be taken up by macrophages in large amounts. Since lungs contain a large number of these cells, it is likely that the drug in the sputum came from lung macrophages. It is also possible that the patient had some lung parenchymal/ alveolar damage which allowed macrophages containing CLO to escape into the bronchial tree and be coughed out with the sputum. These events appear to be episodic because the patient had a variable quantity of CLO in the sputum. In one period the patient coughed out about $4 \mathrm{~g}$ of sputum containing $0.298 \mathrm{mg} / \mathrm{g}$ of CLO, but at a different time, in over $24 \mathrm{hr}, 50 \mathrm{~g}$ of sputum only contained $0.098 \mathrm{mg} / \mathrm{g}$, which shows the great variation in amounts.

To discover the source of this CLO discharge, bronchoscopy would have been the best method, but this was not done because it would have been invasive and not therapeutically useful to the patient. The saliva (collected after chewing sterile rubber) and the patient's gastric aspirate, which was removed 3 hours after the daily dose of CLO, were both free from CLO, therefore ruling out CLO discharge from anywhere but the lungs.

Because of 'haemoptysis' we ruled out tuberculosis, despite this being a very common problem in the tropics, especially in lepromatous patients on steroids. Another possibility, tropical pulmonary eosinophilia, was considered because the patient not only had blood-streaked sputum and mild dyspnoea but also eosinophilia. Also, the temporary remission with DEC further confused the issue. In retrospect, it seems increasingly likely that even the eosinophilia was caused by deposits of CLO in the tissues. Eosinophilia as part of eosinophilic enteritis due to deposits of CLO in the gut is well known, ${ }^{7}$ and it is possible that similar deposits of CLO in lung parenchyma resulted in this patient's eosinophilia.

In conclusion, 'haemoptysis' in some patients with chronic recurrent lepra reactions, who are on a high CLO dosage, could be caused by the coughing out of this drug.

\section{References}

1 Aguas JT. Treatment of leprosy with Lamprene (B 663 Geigy). Int J Lepr, 1971; 39: 493-503. 
2 Leiker DL. Treatment of leprosy with Geigy B 663 (G. 30320). E.A. Lepr Bull, 1970; 1: 9.

3 Conalty ML, Berry VC, Jina A. The anti-leprosy agent B 663 (clofazimine) and the reticulo-endothelial system. Int J Lepr, 1971; 39: 479-492.

${ }^{4}$ Desikan KV, Balakrishnan, S. Tissue levels of clofazimine in a case of leprosy. Lepr Rev, 1976; 47: 107-113.

5 Desikan K V, Ramanujam K, Ramu G, Balakrishnan S. Autopsy findings in a case of lepromatous leprosy treated with clofazimine. Lepr Rev, 1975; 46: 181-189.

6 Lanyi, Z and Dubois, JP. Determination of clofazimine in human plasma by thin layer chromatography. J Chromatogr, 1982; 232: 219-222.

7 Mason GH, Ellies-Pegler RB, Arthur JF. Clofazimine and eosinophilic enteritis. Lepr Rev, 1977; 48: $175-180$.

Lepr Rev (1992) 63, 47-50

\title{
Coloration rouge des crachats par la clofazimine imitant l'hémoptisie: cas clinique
}

\author{
A Girdhar, K Venkatesan, S L Chauhan, G N Malaviya et \\ B K GIRDHAR
}

Résumé Un sujet atteint de lèpre lépromateuse ayant reçu une dose élevée de clofazimine, dans le cadre d'une médication mixte contre la lèpre chronique de forme erythema nodosum leprosum (ENL), souffrait de fréquentes hémoptisies. On a découvert plus tard que cette hémoptisie était due à des expectorations de clofazimine. Ce cas intéressant est peut-être le premier cas de cette espèce signalé.

\section{Una descoloración roja del esputo causada por clofazimina que simula a la hemoptisis}

\author{
A Girdhar, K Venkatesan, S L Chauhan, G N Malaviya y \\ B K GIRDHAR
}

Resumen Un paciente con lepra lepromatosa, que recibió una elevada dósis de clofazimina como parte de una terapia multidroga para el tratamiento de eritema nodosum leprosum crónica (ENL) sufría de una frecuente hemoptisis. Más tarde, se descubrió que la hemoptisis se debía a la expectoración de clofazimina. Se señala este interesante, y posiblemente primer, caso. 